\title{
Optimizing Grain Sorghum (Sorghum bicolor L.) Productivity Under Full Irrigation and Stress Using Humic Acid in Arid Regions
}

\author{
Ismail, S.M. and F.S. El-Nakhlawy
}

${ }^{1}$ Soils and Water Department, Faculty of Agriculture, Assiut University, Egypt

${ }^{2}$ Arid Land Agriculture Department, Faculty of Meteorology, Environment and Arid Land Agriculture, King Abdulaziz University, Jeddah, Saudi Arabia

*Email: saleh.ibrahim@agr.au.edu.eg

Received on: $3 / 3 / 2019$

Accepted for publication on:12/3/2019

\section{Abstract}

A field experiment was carried-out at the Agriculture Research Station of King Abdulaziz University during 2015/16 and 2016/17 seasons to optimize the productivity of grain sorghum under three irrigation water regimes and three humic acid (HA) levels. The first water regime was received the full irrigation water requirement $(100 \% \mathrm{WR})$ while the second and the third water regimes received $80 \%$ and $60 \%$ from the full irrigation water requirements. Water regimes were investigated in main plots. The sub plots were three HA application levels namely: 5, 10 and $15 \mathrm{~kg} / \mathrm{ha}$. Each HA level for each plot was sown on soil surface and manually mixed with the upper $15 \mathrm{~cm}$ of soil surface before each planting date of the two. growing seasons. Results showed that, daily and seasonal water supplies were reduced by decreasing the applied water regimes. As irrigation water regime decreased grain yield and yield components significantly decreased. The average reduction over the two growing seasons in grain yield of sorghum were $4.7 \%$ in $80 \% \mathrm{WR}$ and $25.5 \%$ in $60 \% \mathrm{WR}$ when compared with full irrigation requirement treatment. Using HA by the level of 10 or $15 \mathrm{~kg} / \mathrm{ha}$ as soil amendment improved yield production and yield components in grain sorghum. The increase in grain sorghum yield was $8 \%$ in $10 \mathrm{~kg} / \mathrm{ha}$ level and $17.5 \%$ in $15 \mathrm{~kg} / \mathrm{h}$ HA level when compared with $5 \mathrm{~kg} / \mathrm{ha}$ as an average over the two seasons. Irrigation water use efficiency (IWUE) was increased by decreasing irrigation water regime and increased by increasing HA application level. The IWUE of $80 \%$ WR with $15 \mathrm{~kg} /$ ha was significantly similar with $60 \%$ WR with 10 or $15 \mathrm{~kg} / \mathrm{ha}$ HA level. Finally, and according to the obtained results it can be concluded that $80 \% \mathrm{WR}$ with $15 \mathrm{~kg} /$ ha HA reduced the grain yield by only $4.7 \%$ while saved $20 \%$ of irrigation water.

\section{Keywords: water stress, drip irrigation, soil conditioners, arid regions}

\section{Introduction}

Sorghum can grow as fodder and for human consumption in areas relay under water stress. Sorghum has a high concentration of potassium and starch, it is less acidifying and is easily absorbed and tolerated by the sick and diabetics, adults and even children. Sorghum is a substitute for wheat and is great for those requiring a gluten-free diet. Sorghum is naturally high in fiber and iron, with a high protein level as well. It is rich in antioxidants, which are believed to help lower the risk of cancer, diabetes, heart disease and some neurological diseases. It is also full of policosanols that may have an impact on human cardiac health. Sorghum can remain green in dry season when 
most of the other crops dry up because it can survive when the moisture levels are very low for any plant to grow. When freshly chopped, it can be given to cows, goats, sheep, and even chickens because it has the same energy levels as maize and other cereals. Sorghum produces much more forage than maize. This crop grows again after it is cut for use as fodder and harvesting of the grains, it therefore reduces the costs of replanting, land preparation and time. Forage sorghums use approximately $40-50 \%$ less water than corn to produce the same dry matter. (Miller \& Stroup 2004).

Drought is one of the major limiting factors to agriculture, and considered as the most important cause of yield reduction in crop plants. However, grain sorghum tolerates and avoids drought more than many other cereal crops, but the drought response of sorghum does not come without a yield loss. Menezes et al., (2015) evaluated forty-nine hybrids of grain sorghum under normal irrigation conditions or water stress in order to select those likely to be more tolerant of drought. Grain yield, weight of 1000 grains, harvest index, days to flowering, and plant height were affected by water stress; however, grain yield showed the largest relative reduction. Castro-Nava et al., (2012) found that drought stress significantly reduced grain yield when it was applied at the flag leaf stage (24\%) and at flowering (28\%), but not when drought occurred at panicle initiation. Assefa et al., (2010) found a $36 \%$ sorghum yield reduction when water stress occurred during the vegetative stage and more than $55 \%$ yield reduction with water stress occurring during the reproductive stage. Mahajan \& Tuteja (2005) reported that water stress has diverse effects on physiology and development of sorghum that determines its final yield depending on the development stage at which stress occurs. Water stress occurring between pre- and postflowering in sorghum decreases seed filling duration, seed size and number, thus leading to strong yield reduction or even total crop loss. The high tillering of forage sorghum provides compensation when the main stem is damaged by water stress, fostering yield stability in rainfed areas. Garofalo \& Rinaldi (2013) found that sorghum biomass has a high potential productivity $\left(3-4,000 \mathrm{~g} \mathrm{~m}^{-2}\right)$ of dry matter in Mediterranean environments if it is supplied with an adequate seasonal water amount, not less than $300 \mathrm{~mm}$. However, sorghum showed a good adaptation to water stress.

Focusing on techniques that can improve water availability in summer growing season might be increased the production of summer crops. Because without any management rain or irrigation water may be percolating beyond root-zone, resulted in environmental consequences and diminishes water reserves. Many scientists, agronomists and farmers use humic acid (HA) for improving soil conditions and plant growth. Using such type of soil amendments help to conserve water in root-zone area. Therefore, water availability is increases due to the reductions in run-off and/or deep percolation that will ultimately cause increase in crop yield. Humic compounds can help to im- 
prove the soil structure by increasing the amount of pore space and enhancing the air exchange, water movement, water holding capacity and root growth. As a result, better drought resistance and reduction in water usage can be done (Khattak \& Muhammad, 2006; Almarshadi \& Ismail $2014 \mathrm{a}$ and b). In plants, humic acids have positive effects on enzyme activity, plant nutrients, and growth stimulant and are considered as a "plant food". Humic acid contains $51 \%$ to $57 \% \mathrm{C}, 4 \%$ to $6 \% \mathrm{~N}$ and $0.2 \%$ to $1 \% \mathrm{P}$ and other micronutrients in minute amounts. Therefore, it acts as source of plant nutrients (Tejada \&Gonzalez, 2003; Admas et al., 2015). The contents of humic substance from plant nutrients act as organic fertilizers and are energy sources for bacteria, fungi, and earthworms that live in the soil. Beside their contents from nutrients, humic substances can chelate soil nutrients consequently improve nutrient uptake, especially phosphorous, sulfur and nitrogen because they act as a storehouse of N, P, S, and Zn (Davies et al., 2004; Bandani et al., 2014). Humic acid based fertilizers increase crop yield (Mohamed et al., 2009). As being from the literature, HA considered a vital constituent and a friendly part of soil organic structure. Therefore, the main objectives of the current study were to optimize the productivity of grain sorghum as nutritious and forage crop in the soils treated with humic acid under the scarcity of irrigation water and to maximize irrigation water use efficiency.

\section{Material and Methods}

\section{Experimental location, design and treatments}

To achieve the above-mentioned objectives a field experiment was conducted at the Agriculture Research Station of King Abdulaziz University located at Hada Al-Sham, $110 \mathrm{~km}$ north east of Jeddah, KSA during the two growing seasons of $2015 / 2016$ and 2016/2017. The soil texture of the experimental site was classified as sandy loam. The climate of the area was arid, with high temperatures during summer season. The design of the experiment was split plot with four replications. The main plots were for three irrigation water regimes. The first water regime was full irrigation water requirement and equal $100 \%$ of water requirements $(100 \%$ WR $)$. The second and third water regimes were $80 \%$ and $60 \%$ from the full irrigation water requirements ( $80 \% \mathrm{WR}$ and $60 \% \mathrm{WR})$. The sub-plots were treated with a commercial product of HA, with a granular presentation and a purity of 90\%, produced by Pioneers Chemicals (Saudi Arabia) in three proportions $(5,10$ and $15 \mathrm{~kg} / \mathrm{ha})$. Each humic acid level for each plot (area of the plot $2 \mathrm{~m} * 3 \mathrm{~m}=6 \mathrm{~m}^{2}$ ) was sown on soil surface and manually mixed with the upper $15 \mathrm{~cm}$ of soil surface before each growing season. Surface drip irrigation method was used under the current study. Before installing irrigation networks, the experimental site was ploughed and leveled, and then the irrigation network was installed. The dripper lines were installed on soil surface at $40 \mathrm{~cm}$ between two adjacent dripper lines. The distance between drippers was $30 \mathrm{~cm}$ the type of the dripper line was RAIN 
BIRD LD- 06- 12-1000 Landscape drip 0.9 G/h@12". Inlet pressure on each tape was about 1.5 bars. The system uses 125-micron disk filter. The water source was from the installed containers.

\section{Water requirement calculation}

The required amount of water for each water regime was calculated by CROPWAT model based on the average of 7 years metrological data collected from the weathering station presented in the experimental area as follows:

$$
\mathrm{ETc}=\mathrm{Kc} \times \mathrm{ET} 0
$$

Where: $\underset{(\mathrm{mm} / \mathrm{day})}{\mathrm{ETc}}=$ Crop evapotranspiration

ET0 = Reference evapotranspiration (mm/day)

$\mathrm{Kc}=$ Crop Coefficient.

\section{Reference evapotranspiration} was calculated using Penmanmonteith equation as described by Allen et al., (1998). Also, crop coefficient values for grain sorghum listed by Allen et al. (1998) was used. After water requirements were calculated, the control unit (timer) was adjusted for the required time to supply the calculated required amount of irrigation water. The required irrigation time for $100 \%$ WR treatments was calculated from the dripper discharge, the distance between drippers, and number of drip lines. As the daily water requirement was calculated in $100 \%$ WR treatments it reduced to be $80 \% \mathrm{WR}$ in the second treatment and to be $60 \% \mathrm{WR}$ in the third treatment. Seasonal water supply for each crop was obtained by the summation of daily water supply. The soil preparation, planting date, seeding, fertilization, weeding, and harvesting were done according to El-Nakhlawy \& Ghandorah (2010).

\section{Data collection}

Daily water supply was collected alone each growing season and then the seasonal water supply was calculated. For grain sorghum crop, the following traits were determined on 10 guarded random plants in each sub plot; heading date (no. of days from planting to $50 \%$ heading), plant height $(\mathrm{cm})$. At harvesting, 100- grain weight $(\mathrm{g})$, grain yield/ha $(\mathrm{t})$, biomass yield /ha (t) and loss in yield in relation to irrigation water regimes were measured. Moreover, irrigation water use efficiency (IWUE) and water saving in relation to irrigation water regime were calculated.

\section{Statistical Analysis}

The obtained data in each experiment for each season were statistically analyzed through analysis of variance procedures to determine the significance of the treatments and the interactions. Means were separated and RLSD test was used to compare between the means after applying the statistical analysis assumptions according El-Nakhlawy (2010) using SAS (2006).

\section{Results}

\section{Daily and seasonal water supply}

Results of daily water supply are presented in Figure (1). The results show that, daily water supply for all investigated water regimes along the both growing seasons are increased gradually till reached maximum after about 90 and 60 days from planting in the first and the second seasons respectively. Then start decrease to reach minimum at harvesting. The highest water supply was recorded in $100 \%$ WR treatment fol- 
lowed by $80 \%$ WR and $60 \%$ WR treatment respectively.

Seasonal water supply was obtained from the summation of daily water supply along the growing season. The data are visualized in figure (2). Results clearly show that seasonal water supply was decreased by decreasing irrigation water regime. The least seasonal water supply obtained from $60 \%$ WR treatment followed by $80 \%$ WR treatment. The highest seasonal water supply was recorded in $100 \% \mathrm{WR}$ treatment. The results also clearly indicated that, seasonal water supply of the second growing season was lower than that of the first growing season.

Agronomical traits of grain sorghum

\section{Analysis of variance}

Analysis of variance of the grain sorghum traits under the effects of irrigation water regimes, humic acid levels and their interactions during both growing seasons are presented in Tables (1 and 2).


Figure 1. Daily water supply (mm) for grain sorghum under the effect of different irrigation water regimes during the growing seasons of 2015/16 and 2016/17. 


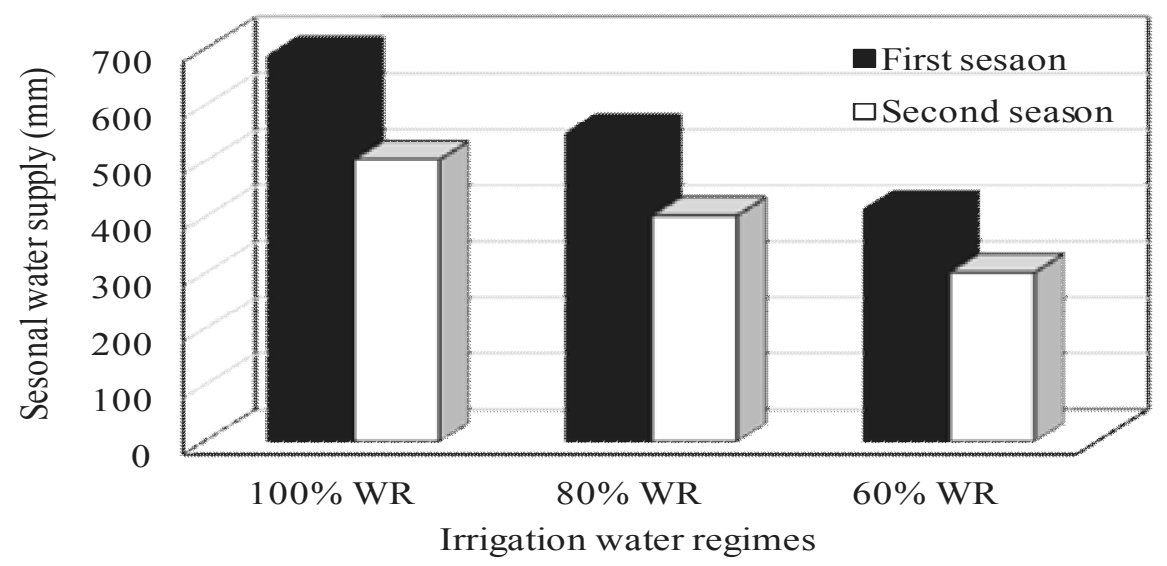

Figure 2. Seasonal water supply (mm) for grain sorghum under the effect of different irrigation water regimes during the growing seasons of 2015/16 and 2016/17.

The results of the analysis of variance showed significant effects for irrigation water regime, HA levels and their interaction on all studied grain sorghum traits and IWUE in both seasons.

\section{Mean comparisons \\ Effect of water regimes}

The statistical comparisons between the means of the studied traits under the three-irrigation water regimes in the two growing seasons using RLSD (0.05) for heading date, plant height and 100 grain weight are presented in Table (3). The results revealed that, heading date significantly decreased as water supply decreased in both seasons. Under $100 \%$ WR, heading dates were 54.08 and
55.60 days in the first and second seasons, respectively. Under the $60 \%$ WR heading dates were 49.58 and 51.43 days in the two seasons, respectively. Plant height means significantly decreased as water requirements decreased in both seasons. The tallest plants mean (124 and 130 . $7 \mathrm{~cm}$ ) were recorded in $100 \%$ WR followed by $(98.0$ and $114.96 \mathrm{~cm})$ in $80 \% \mathrm{WR}$ and $(87.50$ and $91.92 \mathrm{~cm})$ in $60 \%$ WR for the two growing seasons, respectively. Similarly, 100grain weight were significantly reduced by reducing water requirements where the highest 100-grain weight was recorded in $100 \%$ WR while the least was recorder in $60 \%$ WR treatment.

Table 1. Analysis of variance for heading date, plant height and 100-grain weight for grain sorghum during $2015 / 2016$ and $2016 / 2017$ seasons.

\begin{tabular}{|l|c|c|c|c|c|c|c|}
\hline \multirow{2}{*}{ Source of Variation } & \multirow{2}{*}{ df } & \multicolumn{2}{|c|}{$\begin{array}{c}\text { Heading date } \\
\text { (day) }\end{array}$} & \multicolumn{2}{c|}{$\begin{array}{c}\text { Plant height } \\
\text { (cm) }\end{array}$} & \multicolumn{2}{c|}{$\begin{array}{c}\text { 100-grain weight } \\
\text { (g) }\end{array}$} \\
\cline { 3 - 8 } & & $2015 / 16$ & $2016 / 17$ & $2015 / 16$ & $2016 / 17$ & $2015 / 16$ & $2016 / 17$ \\
\hline Replicates & 3 & $3.22 \mathrm{NS}$ & $1.33 \mathrm{NS}$ & $57.59 \mathrm{NS}$ & $33.95 \mathrm{NS}$ & $0.01 \mathrm{NS}$ & $0.24 \mathrm{NS}$ \\
\hline Water Regime (WR) & 2 & $61.19^{* *}$ & $29.36^{* *}$ & $4237.0^{* *}$ & $4653.24^{* *}$ & $0.39^{* *}$ & $0.48^{*}$ \\
\hline Error "a" & 6 & 3.97 & 2.55 & 72.25 & 89.25 & 0.02 & 0.08 \\
\hline Humic acid levels(HA) & 2 & $48.69^{* *}$ & $8.03^{*}$ & $391.58^{*}$ & $142.27^{*}$ & $0.18^{* *}$ & $0.18^{*}$ \\
\hline WR * HA & 4 & $10.98^{* *}$ & $0436^{*}$ & $86.20^{*}$ & $120.47^{*}$ & $0.13^{*}$ & $0.16^{*}$ \\
\hline Error "b" & 18 & 2.78 & 1.36 & 28.03 & 37.81 & 0.02 & 0.05 \\
\hline
\end{tabular}

NS : not significant at at $\mathrm{p} \leq 0.05,{ }^{*}, * *$ : significant at at $\mathrm{p} \leq 0.05$ and at $\mathrm{p} \leq 0.01$, respectively. 
Table 2. Analysis of variance for grain and biomass yields and IWUE for grain sorghum during 2015/2016 and 2016/2017 seasons.

\begin{tabular}{|l|c|c|c|c|c|c|c|}
\hline \multirow{2}{*}{$\begin{array}{c}\text { Source of Varia- } \\
\text { tion }\end{array}$} & \multirow{2}{*}{ df } & \multicolumn{2}{c|}{$\begin{array}{c}\text { Grain yield } \\
\text { (t/ha) }\end{array}$} & \multicolumn{2}{c|}{$\begin{array}{c}\text { Biomass yield } \\
\text { (t/ha) }\end{array}$} & \multicolumn{2}{c|}{$\begin{array}{c}\text { IWUE } \\
\mathbf{k g} / \mathbf{m m} / \mathbf{h a}\end{array}$} \\
\cline { 3 - 8 } & $2015 / 16$ & $2016 / 17$ & $2015 / 16$ & $2016 / 17$ & $2015 / 16$ & $2016 / 17$ \\
\hline Replicates & 3 & $0.27 \mathrm{NS}$ & $0.13 \mathrm{NS}$ & $\begin{array}{c}12.52 \\
\mathrm{NS}\end{array}$ & $21.36 \mathrm{NS}$ & $3.02 \mathrm{NS}$ & $1.67 \mathrm{NS}$ \\
\hline Water Regime (WR) & 2 & $7.58^{* *}$ & $1.44^{* *}$ & $350.17^{* *}$ & $184.40^{* *}$ & $10.18^{* *}$ & $10.99^{*}$ \\
\hline Error "a" & 6 & 0.06 & 0.12 & 21.58 & 12.73 & 1.12 & 1.56 \\
\hline $\begin{array}{l}\text { Humic acid levels } \\
\text { (HA) }\end{array}$ & 2 & $2.35^{* *}$ & $0.46^{*}$ & $20.23^{*}$ & $0.86 \mathrm{NS}$ & $6.42^{* *}$ & $5.09^{*}$ \\
\hline WR * HA & 4 & $0.37^{*}$ & $0.36^{*}$ & $24.80^{*}$ & $27.86^{*}$ & $4.89^{* *}$ & $4.22^{*}$ \\
\hline Error "b" & 18 & 0.05 & 0.09 & 4.11 & 5.35 & 0.79 & 1.32 \\
\hline
\end{tabular}

NS : not significant at at $\mathrm{p} \leq 0.05,{ }^{*}, * *$ : significant at at $\mathrm{p} \leq 0.05$ and at $\mathrm{p} \leq 0.01$, respectively.

Results of grain and biomass yields and IWUE are presented in Table (4). Results revealed a reduction in grain yield by reducing the water requirements. The reduction in grain yield/ha recorded in the treatment of $80 \%$ WR was only $1.36 \%$ and $8 \%$ in the first and second season, respectively as compared with $100 \%$ WR. When water regime was reduced to be $60 \%$ WR the reduction in grain yield was sharply decreased to be $24.2 \%$ and $26.8 \%$ in the two seasons. Biomass yield/ha ranged from 21.06 to $10.44 \mathrm{t} / \mathrm{ha}$ in the first season and from 18.99 to $9.81 \mathrm{t} / \mathrm{ha}$ in the second season under $100 \%$ WR and $60 \%$ WR treatments, respectively.

Table 3. Means of heading date, plant height and 100-grain weight for grain sorghum under the effect of irrigation water regime in the growing seasons of 2015/16 and 2016/17.

\begin{tabular}{|l|c|c|c|c|c|c|}
\hline \multirow{2}{*}{$\begin{array}{l}\text { Investigated water } \\
\text { regimes }\end{array}$} & \multicolumn{2}{|c|}{$\begin{array}{c}\text { Heading date } \\
\text { (day) }\end{array}$} & \multicolumn{2}{c|}{$\begin{array}{c}\text { Plant height } \\
\text { (cm) }\end{array}$} & \multicolumn{2}{c|}{$\begin{array}{c}\text { 100-grain weight } \\
\text { (g) }\end{array}$} \\
\cline { 2 - 7 } & $2015 / 16$ & $2016 / 17$ & $2015 / 16$ & $2016 / 17$ & $2015 / 16$ & $2016 / 17$ \\
\hline $100 \% \mathrm{WR}$ & $54.08 \mathrm{a}^{*}$ & $55.60 \mathrm{a}$ & $124.00 \mathrm{a}$ & $130.67 \mathrm{a}$ & $2.28 \mathrm{a}$ & $2.83 \mathrm{a}$ \\
\hline $80 \% \mathrm{WR}$ & $51.50 \mathrm{~b}$ & $54.05 \mathrm{~b}$ & $98.00 \mathrm{~b}$ & $114.96 \mathrm{~b}$ & $2.17 \mathrm{a}$ & $2.42 \mathrm{~b}$ \\
\hline $60 \% \mathrm{WR}$ & $49.58 \mathrm{~b}$ & $51.43 \mathrm{c}$ & $87.50 \mathrm{c}$ & $91.92 \mathrm{c}$ & $1.93 \mathrm{~b}$ & $2.12 \mathrm{c}$ \\
\hline RLSD $(0.05)$ & 1.90 & 1.07 & 8.49 & 9.64 & 0.15 & 0.29 \\
\hline
\end{tabular}

*Means followed by the same letter are not significantly different according to RLSD at $\mathrm{p} \leq 0.05$.

Irrigation water use efficiency (IWUE) significantly increased by decreasing irrigation water regimes from $100 \%$ WR to $80 \% \mathrm{WR}$ and $60 \%$ WR treatments. No significant differences were found between IWUE of
$80 \%$ WR and $60 \%$ WR. The least IWUE $(8.51 \mathrm{~kg} / \mathrm{mm} / \mathrm{ha}$ and 11.10 $\mathrm{kg} / \mathrm{mm} / \mathrm{ha}$ ) were measured in $100 \%$ WR treatment in the first and second season, respectively. IWUE of $80 \%$ WR and $60 \%$ WR treatments were 
significantly similar. IWUE means were 10.50 and $10.79 \mathrm{~kg} / \mathrm{mm} / \mathrm{ha}$ in the first season and 12.76 and 13.55 $\mathrm{kg} / \mathrm{mm} / \mathrm{ha}$ in the second season for $80 \% \mathrm{WR}$ and $60 \% \mathrm{WR}$ treatments, respectively.

Table 4. Means of grain and biomass yields and IWUE for grain sorghum under the effect of irrigation water regime in the growing seasons of 2015/16 and 2016/17.

\begin{tabular}{|l|c|c|c|c|c|c|}
\hline \multirow{2}{*}{$\begin{array}{l}\text { Investigated water re- } \\
\text { gimes }\end{array}$} & \multicolumn{2}{|c|}{$\begin{array}{c}\text { Grain yield } \\
\text { (t/ha) }\end{array}$} & \multicolumn{2}{c|}{$\begin{array}{c}\text { Biomass yield } \\
\text { (t/ha) }\end{array}$} & \multicolumn{2}{c|}{$\begin{array}{c}\text { IWUE } \\
\mathbf{k g} / \mathbf{m m} / \mathbf{h a}\end{array}$} \\
\cline { 2 - 7 } & $2015 / 16$ & $2016 / 17$ & $2015 / 16$ & $2016 / 17$ & $2015 / 16$ & $2016 / 17$ \\
\hline $100 \% \mathrm{WR}$ & $5.87 \mathrm{a} *$ & $5.60 \mathrm{a}$ & $21.06 \mathrm{a}$ & $19.66 \mathrm{a}$ & $8.51 \mathrm{~b}$ & $11.10 \mathrm{~b}$ \\
\hline $80 \% \mathrm{WR}$ & $5.79 \mathrm{a}$ & $5.15 \mathrm{~b}$ & $17.10 \mathrm{a}$ & $16.13 \mathrm{a}$ & $10.50 \mathrm{a}$ & $12.76 \mathrm{a}$ \\
\hline $60 \% \mathrm{WR}$ & $4.45 \mathrm{~b}$ & $4.10 \mathrm{c}$ & $10.44 \mathrm{~b}$ & $9.81 \mathrm{~b}$ & $10.79 \mathrm{a}$ & $13.55 \mathrm{a}$ \\
\hline RLSD $(0.05)$ & 0.23 & 0.35 & 4.64 & 3.56 & 1.19 & 1.27 \\
\hline
\end{tabular}

"Means followed by the same letter are not significantly different according to RLSD at $p \leq 0.05$. IWUE: irrigation water use efficiency

\section{Effect of humic acid levels}

Means of heading date, plant height and 100- grain weight for grain sorghum traits as affected by HA levels in the two growing seasons are presented in (Table 5). Results revealed that, heading date delayed by 2.4 and 4.0 days in 10 and 15 $\mathrm{kg} / \mathrm{ha}$ HA levels when compared with $5 \mathrm{~kg} / \mathrm{ha}$ HA levels in the first season. In the second season no significantly difference was found between 10 and $15 \mathrm{~kg} / \mathrm{ha} \mathrm{HA}$ levels in the heading date but they significantly different from that of $5 \mathrm{~kg} / \mathrm{ha} \mathrm{HA}$. Heading dates in the second season ranged from 52.25 days in $5 \mathrm{~kg} / \mathrm{ha} \mathrm{HA}$ to 54.95 days in $15 \mathrm{~kg} / \mathrm{ha}$ HA levels. No significantly differences were found among plant height means under 10 and $15 \mathrm{~kg} / \mathrm{ha}$ HA levels in both seasons. The tallest plants were recorded under the highest HA levels and the shortest were measured under the lowest HA levels.

Table 5. Means of heading date, plant height and 100-grain weight for grain sorghum under the effect of humic acid levels in the growing seasons of 2015/16 and 2016/17

\begin{tabular}{|l|c|c|c|c|c|c|}
\hline \multirow{2}{*}{ Humic acid levels } & \multicolumn{2}{|c|}{$\begin{array}{c}\text { Heading date } \\
\text { (day) }\end{array}$} & \multicolumn{2}{c|}{$\begin{array}{c}\text { Plant height } \\
\text { (cm) }\end{array}$} & \multicolumn{2}{c|}{$\begin{array}{c}\text { 100-grain weight } \\
\text { (g) }\end{array}$} \\
\cline { 2 - 7 } & $2015 / 16$ & $2016 / 17$ & $2015 / 16$ & $2016 / 17$ & $2015 / 16$ & $2016 / 17$ \\
\hline $5 \mathrm{~kg} / \mathrm{ha}$ & $49.58 \mathrm{c}^{*}$ & $52.25 \mathrm{~b}$ & $97.08 \mathrm{~b}$ & $109.50 \mathrm{~b}$ & $2.03 \mathrm{~b}$ & $2.36 \mathrm{~b}$ \\
\hline $10 \mathrm{~kg} / \mathrm{ha}$ & $52.00 \mathrm{~b}$ & $54.45 \mathrm{a}$ & $104.00 \mathrm{a}$ & $111.95 \mathrm{ab}$ & $2.09 \mathrm{~b}$ & $2.47 \mathrm{ab}$ \\
\hline $15 \mathrm{~kg} / \mathrm{ha}$ & $53.58 \mathrm{a}$ & $54.95 \mathrm{a}$ & $108.42 \mathrm{a}$ & $116.10 \mathrm{a}$ & $2.26 \mathrm{a}$ & $2.55 \mathrm{a}$ \\
\hline $\mathrm{RLSD}(0.05)$ & 1.24 & 0.88 & 5.28 & 5.52 & 0.12 & 0.20 \\
\hline
\end{tabular}

${ }^{*}$ Means followed by the same letter(s) are not significantly different according to RLSD at $\mathrm{p} \leq 0.05$

Plant height means ranged from 97.08 , to $108.42 \mathrm{~cm}$ in the first season and from $109.50 \mathrm{~cm}$ to $116.10 \mathrm{~cm}$ in the second season. 100-grain weights were increased by increasing HA application levels however, the 
increase was significant only between $15 \mathrm{~kg} / \mathrm{ha}$ and the other treatments. The increase in 100-grain weights of $80 \%$ WR and 60\% WR treatments was statistically similar.

Results of the effect of humoc acid application levels on grain and biomass yields and IWUE are presented in Table (6). Results indicated that, grain yield/ha significantly increased by increasing HA levels in both seasons. The increases in grain yield were $9.35 \%$ and $18.09 \%$ in the first season and 8.35 and $16.8 \%$ in the second season for 10 and $15 \mathrm{~kg} / \mathrm{ha}$ HA levels when compared with the grain yield of $5 \mathrm{~kg} /$ ha HA levels. No significantly differences were found in biomass yield/ha when comparing 10 and $15 \mathrm{~kg} / \mathrm{ha} \mathrm{HA}$ levels or when comparing 5 and $10 \mathrm{~kg} / \mathrm{ha}$ HA levels in both seasons. Biomass yield/ha ranged from 15.19 to $17.17 \mathrm{t} / \mathrm{ha}$ in the first season and from 13.66 to 16.68 $\mathrm{t} / \mathrm{ha}$ in the second season. No significant differences were found between IWUE means under 10 and $15 \mathrm{~kg} / \mathrm{ha}$ HA levels or between 5 and $10 \mathrm{~kg} / \mathrm{ha}$ HA levels in both seasons. The highest IWUE (10.82 and 13.44 $\mathrm{kg} / \mathrm{mm} / \mathrm{ha}$ ) were obtained from the treatment of $15 \mathrm{~kg} / \mathrm{ha}$ HA levels in the two seasons, respectively. The least significant IWUE was found in the treatment of $5 \mathrm{~kg} / \mathrm{ha} \mathrm{HA}$ levels with values of 9.05 and 11.51 $\mathrm{kg} / \mathrm{mm} / \mathrm{ha}$ in the first and second seasons, respectively.

Effect of the interaction between water regimes and humic acid levels

Means of heading date, plant height and 100-grain weight as affected by the interaction between the irrigation water regimes and humic acid levels in the two growing seasons are presented in Table (7). Results showed that, the highest heading dates in all interaction treatments were 57.24 and 56.80 days which recorded in $100 \%$ WR with $15 \mathrm{~kg}$ $\mathrm{HA} / \mathrm{ha}$ in the first and the second seasons, respectively. No significant differences were found among heading dates of the treatments of $60 \% \mathrm{WR}+$ $15 \mathrm{~kg} / \mathrm{ha} \mathrm{HA}, 60 \% \mathrm{WR}+10 \mathrm{~kg} / \mathrm{ha}$ $\mathrm{HA}, 80 \% \mathrm{WR}+10 \mathrm{~kg} / \mathrm{ha} \mathrm{HA}$ and $80 \% \mathrm{WR}+5 \mathrm{~kg} / \mathrm{ha} \mathrm{HA}$ in the first season. In the second season no significant differences were found between heading dates of $80 \% \mathrm{WR}+10$ or $15 \mathrm{~kg} / \mathrm{ha} \mathrm{HA}$ and $100 \% \mathrm{WR}+5$ $\mathrm{kg} / \mathrm{ha}$ HA levels. Heading date ranged from 57.24 to 48.5 days in the first season and from 56.80 to 50 days in the second season. 
Table 6. Means of grain and biomass yields and IWUE for grain sorghum under the effect of humic acid levels in the growing seasons of 2015/16 and 2016/17

\begin{tabular}{|l|c|c|c|c|c|c|}
\hline \multirow{2}{*}{ Humic acid levels } & \multicolumn{2}{|c|}{$\begin{array}{c}\text { Grain yield } \\
\text { (t/ha) }\end{array}$} & \multicolumn{2}{c|}{$\begin{array}{c}\text { Biomass yield } \\
\text { (t/ha) }\end{array}$} & \multicolumn{2}{c|}{$\begin{array}{c}\text { IWUE } \\
\text { kg/mm/ha }\end{array}$} \\
\cline { 2 - 8 } & $2015 / 16$ & $2016 / 17$ & $2015 / 16$ & $2016 / 17$ & $2015 / 16$ & $2016 / 17$ \\
\hline $5 \mathrm{~kg} / \mathrm{ha}$ & $4.92 \mathrm{c}^{*}$ & $4.57 \mathrm{c}$ & $15.19 \mathrm{~b}$ & $13.66 \mathrm{~b}$ & $9.05 \mathrm{~b}$ & $11.51 \mathrm{~b}$ \\
\hline $10 \mathrm{~kg} / \mathrm{ha}$ & $5.38 \mathrm{~b}$ & $4.95 \mathrm{~b}$ & $16.76 \mathrm{ab}$ & $\begin{array}{c}15.27 \\
\mathrm{ab}\end{array}$ & $9.93 \mathrm{ab}$ & $12.46 \mathrm{ab}$ \\
\hline $15 \mathrm{~kg} / \mathrm{ha}$ & $5.81 \mathrm{a}$ & $5.34 \mathrm{a}$ & $17.17 \mathrm{a}$ & $16.68 \mathrm{a}$ & $10.82 \mathrm{a}$ & $13.44 \mathrm{a}$ \\
\hline RLSD $(0.05)$ & 0.22 & 0.27 & 1.75 & 2.08 & 0.98 & 1.03 \\
\hline
\end{tabular}

Means followed by the same letter(s) are not significantly different according to RLSD at $p \leq 0.05$. IWUE: irrigation water use efficiency

Plant height means under the 9 interaction treatments showed that all HA levels for $100 \%$ WR produced the tallest plants in both seasons. No significant differences were found between the $80 \% \mathrm{WR}+15 \mathrm{~kg} / \mathrm{ha} \mathrm{HA}$ when compared with the treatments of $100 \% \mathrm{WR}+5 \mathrm{~kg} / \mathrm{ha} \mathrm{HA}$ levels in the second season. In the first season plant height means ranged from $128.26 \mathrm{~cm}$ to $83.77 \mathrm{~cm}$ while in the second season ranged from 134.24 $\mathrm{cm}$ to $88.50 \mathrm{~cm}$ under the treatments of $100 \% \mathrm{WR}+15 \mathrm{~kg} / \mathrm{ha} \mathrm{HA}$ and $60 \% \mathrm{WR}+5 \mathrm{~kg} / \mathrm{ha}$ HA levels, respectively.

No significant difference was found between 100-grain weight under $100 \%$ WR with $5 \mathrm{~kg} / \mathrm{ha} \mathrm{HA}$ and $80 \%$ WR with $15 \mathrm{~kg} /$ ha HA. The 100 -grain weight ranged from $2.40 \mathrm{~g}$ to $1.71 \mathrm{~g}$ in the first season and from 2.92 to 2.01 in the second season under the treatments of $100 \%$ WR with $15 \mathrm{~kg} / \mathrm{ha} \mathrm{HA}$ and $60 \% \mathrm{WR}$ with5 $\mathrm{kg} /$ ha HA levels, respectively.

Table 7. Means of heading date, plant height and 100-grain weight for grain sorghum under the effect of the interaction between irrigation water regimes and humic acid levels for the growing seasons of 2015/16 and 2016/17.

\begin{tabular}{|c|c|c|c|c|c|c|c|}
\hline \multirow{2}{*}{$\begin{array}{c}\text { Irrigation } \\
\text { water } \\
\text { regime }\end{array}$} & $\begin{array}{c}\text { Humic } \\
\text { acid lev- } \\
\text { els } \\
\text { (kg/ha) }\end{array}$ & \multicolumn{2}{|c|}{$\begin{array}{c}\text { Heading date } \\
\text { (day) }\end{array}$} & \multicolumn{2}{|c|}{$\begin{array}{c}\text { Plant height } \\
\text { (cm) }\end{array}$} & \multicolumn{2}{|c|}{$\begin{array}{c}\text { 100-grain weight } \\
\text { (g) }\end{array}$} \\
\cline { 2 - 8 } & $2015 / 16$ & $2016 / 17$ & $2015 / 16$ & $2016 / 17$ & $2015 / 16$ & $2016 / 17$ \\
\hline \multirow{2}{*}{$\begin{array}{c}100 \% \\
\text { WR }\end{array}$} & 5 & 51.25 & 54.00 & 119.10 & 127.65 & 2.21 & 2.72 \\
\cline { 2 - 8 } & 10 & 53.76 & 56.00 & 124.75 & 130.11 & 2.24 & 2.85 \\
\hline \multirow{3}{*}{$80 \% \mathrm{WR}$} & 15 & 57.24 & 56.80 & 128.26 & 134.24 & 2.40 & 2.92 \\
\cline { 2 - 8 } & 10 & 49.00 & 52.75 & 88.50 & 112.36 & 2.16 & 2.34 \\
\hline \multirow{3}{*}{$60 \% \mathrm{WR}$} & 15 & 54.28 & 55.55 & 109.05 & 118.25 & 2.24 & 2.50 \\
\cline { 2 - 8 } & 5 & 48.50 & 50.00 & 83.77 & 88.50 & 1.71 & 2.01 \\
\cline { 2 - 8 } & 10 & 51.00 & 51.80 & 90.78 & 91.46 & 1.94 & 2.13 \\
\hline \multicolumn{2}{|c|}{$\mathrm{RLSD}(0.05)$} & 49.25 & 52.50 & 88.02 & 95.80 & 2.14 & 2.24 \\
\hline
\end{tabular}


Concerning grain yield/ha under the effects of the interaction treatments, the results presented in Table (8) showed that, the highest grain yield/ha produced from $100 \%$ WR with $15 \mathrm{~kg} / \mathrm{ha} \mathrm{HA}$ and $80 \%$ WR with $15 \mathrm{~kg} / \mathrm{ha} \mathrm{HA}$ in the first season.

Table 8. Means of grain and biomass yields and IWUE for grain sorghum under the effect of the interaction between irrigation water regimes and humic acid levels for the growing seasons of 2015/16 and 2016/17

\begin{tabular}{|c|c|c|c|c|c|c|c|}
\hline \multirow{2}{*}{$\begin{array}{c}\text { Irrigation } \\
\text { water } \\
\text { regime }\end{array}$} & $\begin{array}{c}\text { Humic acid } \\
\text { level } \\
\text { (kg/ha) }\end{array}$ & \multicolumn{2}{|c|}{$\begin{array}{c}\text { Grain yield } \\
\text { (t/ha) }\end{array}$} & \multicolumn{2}{c|}{$\begin{array}{c}\text { Biomass yield } \\
\text { (t/ha) }\end{array}$} & \multicolumn{2}{c|}{$\begin{array}{c}\text { IWUE } \\
\mathbf{k g} / \mathbf{m m} / \mathbf{h a}\end{array}$} \\
\cline { 2 - 8 } & $2015 / 16$ & $2016 / 17$ & $2015 / 16$ & $2016 / 17$ & $2015 / 16$ & $2016 / 17$ \\
\hline \multirow{2}{*}{$\begin{array}{c}100 \% \\
\mathrm{WR}\end{array}$} & 5 & 5.46 & 5.08 & 19.97 & 17.22 & 7.93 & 10.07 \\
\cline { 2 - 8 } & 10 & 5.89 & 5.61 & 21.21 & 19.74 & 8.56 & 11.12 \\
\cline { 2 - 8 } & 15 & 6.23 & 6.12 & 22.01 & 22.02 & 9.05 & 12.13 \\
\hline \multirow{3}{*}{$80 \% \mathrm{WR}$} & 5 & 5.55 & 4.85 & 16.78 & 15.41 & 10.08 & 12.01 \\
\cline { 2 - 8 } & 10 & 5.74 & 5.14 & 17.62 & 15.58 & 10.34 & 12.73 \\
\hline \multirow{3}{*}{$60 \% \mathrm{WR}$} & 15 & 6.10 & 5.46 & 18.04 & 17.41 & 11.08 & 13.52 \\
\cline { 2 - 8 } & 5 & 3.77 & 3.77 & 8.83 & 8.34 & 9.13 & 12.45 \\
\cline { 2 - 8 } & 10 & 4.50 & 4.10 & 11.03 & 10.48 & 10.90 & 13.54 \\
\hline RLSD (0.05) & 15 & 5.09 & 4.44 & 11.46 & 10.62 & 12.33 & 14.66 \\
\hline
\end{tabular}

No significant differences were found between grain yield/ha under $80 \%$ WR with $10 \mathrm{~kg} / \mathrm{ha}$ or $15 \mathrm{~kg} / \mathrm{ha}$ HA and $100 \%$ WR with $5 \mathrm{~kg} / \mathrm{ha}$ HA. Grain yield/ha ranged from 6.23 to $3.77 \mathrm{t} / \mathrm{ha}$ in the first season and from 6.12 to $3.77 \mathrm{t} / \mathrm{ha}$ in the second season under the treatments of $100 \%$ WR with $15 \mathrm{~kg} / \mathrm{ha} \mathrm{HA}$ and $60 \% \mathrm{WR}$ with $5 \mathrm{~kg} / \mathrm{ha} \mathrm{HA}$ levels. Biomass yield/ha as affected by the interaction treatments showed insignificant differences among the treatments of the $100 \%$ WR with $5 \mathrm{~kg} / \mathrm{ha} \mathrm{HA}$ and $80 \%$ WR with 10 or $15 \mathrm{~kg} / \mathrm{ha} \mathrm{HA}$ in both seasons.

The biomass yield/ha ranged from 22.01 to $8.83 \mathrm{t} / \mathrm{ha}$ in the first season and from 22.02 to $8.34 \mathrm{t} / \mathrm{ha}$ in the second season under the treatment of $100 \%$ WR with $15 \mathrm{~kg} / \mathrm{ha} \mathrm{HA}$ and $60 \%$ WR with $5 \mathrm{~kg} / \mathrm{ha}$ HA levles, respectively. Results of IWUE as affect by the interaction treatments indi- cated that, the highest IWUE was obtained from the treatment of $60 \% \mathrm{WR}$ with $15 \mathrm{~kg} / \mathrm{ha} \mathrm{HA}$ and were 12.33 and $14.66 \mathrm{~kg} / \mathrm{mm} / \mathrm{ha}$ in the first and second seasons, respectively. The least IWUE were obtained from $100 \%$ WR treatment under $5 \mathrm{~kg} / \mathrm{ha}$ HA application level.

Water saving in relation to water regimes

Results presented in table (9) for loss in yield and water saving in relation to applied water regimes indicated that, decreasing irrigation water regime from $100 \%$ WR to $80 \% \mathrm{WR}$ reduced grain yield by only $1.36 \%$ in the first season and by $8.07 \%$ in the second season. Further reduction in water supply to be $60 \%$ of crop water requirement severely reduced grain yield by $24.19 \%$ in the first season and 26.78 in the second season. the reduction in grain yield was met by large amount of water saving. The 
saved water from crop water requirement reduction were $20 \%$ and $40 \%$ of irrigation water supply for
$80 \% \mathrm{WR}$ and $60 \% \mathrm{WR}$ treatments respectively.

Table 9. Means of grain yield, total water supply, loss in yield and water saving of grain sorghum under the effects irrigation water regime during the growing seasons of 2015/2016 and 2016/2017.

\begin{tabular}{|c|c|c|c|c|c|c|c|c|}
\hline \multirow{2}{*}{$\begin{array}{l}\text { Irrigation } \\
\text { water regime } \\
\text { (WR\%) }\end{array}$} & \multicolumn{2}{|c|}{$\begin{array}{c}\text { Grain yield } \\
(\mathbf{k g} / \mathbf{h a})\end{array}$} & \multicolumn{2}{|c|}{$\begin{array}{c}\text { Total water sup- } \\
\text { ply } \\
\text { (mm) }\end{array}$} & \multicolumn{2}{|c|}{$\begin{array}{c}\text { Loss in yield in } \\
\text { relation to WR } \\
(\%) \\
\end{array}$} & \multicolumn{2}{|c|}{$\begin{array}{c}\text { Water saving in } \\
\text { relation to WR } \\
(\%)\end{array}$} \\
\hline & $2015 / 16$ & $2016 / 17$ & $2015 / 16$ & $2016 / 17$ & $2015 / 16$ & $2016 / 17$ & $2015 / 16$ & $2016 / 17$ \\
\hline $100 \% \mathrm{WR}$ & 5870 & 5600 & 688.1 & 504.6 & - & - & - & - \\
\hline $80 \% \mathrm{WR}$ & 5790 & 5150 & 550.5 & 403.7 & 1.36 & 8.07 & 20.0 & 20.0 \\
\hline $60 \% \mathrm{WR}$ & 4450 & 4100 & 412.8 & 302.8 & 24.19 & 26.78 & 40.0 & 40.0 \\
\hline
\end{tabular}

\section{Discussions}

\section{Daily and season water supply}

There were gradual reduction in daily and seasonal water supply as a result of reducing water regimes from $100 \%$ WR to $80 \%$ WR and $60 \%$ WR. This behavior is expected because the supplied water was only $80 \%$ and $60 \%$ of full water requirement $(100 \%$ WR). Similar results were reported by, Ismail (2016); Ismail \& Almarshadi (2013). Results also showed that, seasonal water supply during the second growing season was lower than that of the first growing season. The results might be attributed to the length of the growing season and the time of cultivation. The length of the second growing season was reduced by about one month compared to the first season. This reduction in growing season met by a reduction in seasonal water supply as clearly indicated by the results. Time of planting for the first season was at late November, while the planting time was at November $1^{\text {st }}$ in the second growing season. As a result, the growth period during the first season was continue up to April but in the second growing season the growth period continue up to march. Due to the change in weather conditions especially temperature, relative humidity and wend speed the crop water requirement gradually increased from January to April, therefore the crop water requirement in the first season was higher than that of the second growing season. Irrigation amount varied with weather conditions, irrigation methods and levels (Ismail, 2012; Ismail \& Almarshdi, 2013).

Effect of irrigation water regimes on yield and yield components

Drought stress caused a significant reduction in most of the studied grain sorghum characters. In cereals, yield losses are caused mainly by the reduction in starch accumulation during flowering or grain development (Barnabás et al., 2008). The effects of drought on grain sorghum depended on when drought stress occurred during development (Castro-Nava et al., 2012).

Grain yield/ha significantly decreased as irrigation water requirement decreased from $100 \%$ to $80 \%$ and $60 \%$. This significant decrease in the grain yield/ha might be due to the adversely effects of the irrigation wa- 
ter stress on the physiological, biochemical and metabolism procedures within the plants. Water stress reduces photosynthesis; the most important physiological processes that regulate development and productivity of plants (Menezes et al., 2015; Hamza et al., 2016). The reductions in seed yield components due to the decrease in irrigation water supply might be due to the decline in plant height, leaf gas exchange and leaf area, which resulted in reduction of photosynthetic level due to the unavailability of water nutrients in the soil (Ghaafar et al., 2014; Bandani et al., 2014).

Effect of humic acid on yield and yield components

The obtained results showed an increase in the grain yield, yield components by increasing HA levels. The results might be due to the positive effects of HA in improving physical (Almarshadi \& Ismail 2014b), chemical and biological properties of soils (Mikkelsen, 2005). The role of HA is well known in controlling soil-borne diseases, improving soil health, nutrient uptake by plants, mineral availability and fruit quality, etc (Mauromicale et al., 2011). Humic acid based fertilizers increase crop yield (Mohamed et al., 2009), stimulate plant enzymes/hormones and improve soil fertility in an ecologically and environmentally benign manner (Sarir et al., 2005). Humic acid increased the level of adsorption of mineral ions on root surfaces and their penetration into the cells of the plant tissue (Sarwar et al., 2014). Humic acid contains $51 \%$ to $57 \% \mathrm{C}, 4 \%$ to $6 \% \mathrm{~N}$ and $0.2 \%$ to $1 \% \mathrm{P}$ and other micronutri- ents in minute amounts. Therefore, it acts as source of plant nutrients (Tejada \& Gonzalez., 2003). Beside their contents from nutrients, humic substances can chelate soil nutrients consequently improve nutrient uptake, especially phosphorous, sulfur and nitrogen because they act as a storehouse of $\mathrm{N}, \mathrm{P}, \mathrm{S}$, and $\mathrm{Zn}$ (Davies et al., 2004).

Effect of water regimes and humic acid on irrigation water use efficiency

Results clearly showed an increase in IWUE by decreasing water regime and increasing HA application level. The increase in IWUR as a reduction of water regime might be due to several reasons. Water stress under low water regimes $(80 \% \mathrm{WR}$ and $60 \% \mathrm{WR}$ ) decreased losses especially runoff and deep percolation. IWUE was found to increase as a result of reducing deep percolation, canopy interception, soil type, and cultural and management practices (Ismail, 2016). Increasing yields under water stress treatment due to the wise use of irrigation water by investigated crops increase IWUE. Similar results reported by Lindenmayer et al. (2008), and Ismail (2016). Irrigation water use efficiency was also increased by increasing HA application level. The results might be due to the enhancement in retained soil water under high level of HA. Increasing soil water content increased yield production because the growth and yield is a great concern with improves soil conditions including water availability. All of the above mentioned factors increased yield production per unit of water consequently increased IWUE, (Madani et al., 2012; Ismail 
\& Almarshadi 2013; Ismail 2016; Ihsan et al., 2016).

\section{Conclusions}

The obtained results clearly revealed that, daily and seasonal water supplies were reduced by decreasing the applied water regimes. As irrigation water regime decreased yield and yield, components significantly decreased. The reduction in grain yield of sorghum were $4.7 \%$ and $25.5 \%$ for the same treatments over two growing seasons. Using HA by the levels of 10 or $15 \mathrm{~kg} / \mathrm{ha}$ as soil amendment improved yield production and yield components in grain sorghum. The increase in grain sorghum yield was $8 \%$ and $17.5 \%$ for the same treatments over the two growing seasons. No significant differences were showed between gain yield, biomass yield and yield components under 10 and $15 \mathrm{~kg} / \mathrm{ha} \mathrm{HA}$ levels. IWUE was increased by decreasing irrigation water regime and increased by increasing HA application level. The IWUE of $80 \%$ WR with $15 \mathrm{~kg} /$ ha was significantly similar with $60 \%$ WR with 10 or $15 \mathrm{~kg} / \mathrm{ha}$ HA levels. The results clearly indicated that $80 \% \mathrm{WR}$ with $15 \mathrm{~kg} / \mathrm{ha} \mathrm{HA}$ treatment could be the best treatment to be applied under the condition of this experiment because it reduced the yield by about $1.36 \%-8.07 \%$ while saved $20 \%$ of irrigation water.

\section{References}

Admas, H., H. Gebrekindan, B. bedadi and E. Adgo, 2015. Effects of organic and inorganic fertilizers on yield and yield components of maize at Wujiraba Watershed, Northwest Highlands of Etiopia. American J. of Plant Nutrition and Fertilization Technology 5: 1-15.
Allen, R.G., L.S. Pereira, D. Raes and D. Smith. 1998. Crop Evapotranspiration Guide liens for computing crop water requirements- FAO Irrigation and drainage paper No. 56. FAO, Roms, Italy.

Almarshadi, M.S. and S.M. Ismail, 2014a. Barley growth and productivity as affected by soil amendments under fully and minimum irrigation conditions in Saudi Arabia. Life Sci Journal, 11: 223-230.

Almarshadi, M.S. and S.M. Ismail, 2014b. Improving light textured soil properties by water regimes and soil amendments under dry land conditions. Life Science Journal, 11: 264-270.

Assefa, Y., A.S. Staggenborg and V.P.V. Prasad, 2010. Grain sorghum water requirement and responses to drought stress: A Review. Crop management Vol 9 No 1 doi:10.1094/CM-2010-1109-01RV.

Bandani, M.M., R.H. Mobasser and A Sirusmehr. 2014. Effect of Organic Fertilizer on quantitative yield of mung beam (Vigna radiata L). Journal of Novel Applied Sciences 3-4: 367-370.

Barnabás, B., K. Jäger and A. Fehér, 2008. The effect of drought and heat stress on reproductive processes in cereals. Plant Cell and Environment 31: 11-38.

Castro-Nava, S., J. Ortiz-Cereceres, M. Mendoza-Castillo and A. Huerta, 2012. Biomass production and grain yield of three sorghum lines differing in drought resistance. FYTON 81:149 - 156.

Davies, L.C., J.M. Novais and S. Martins-Dias, 2004. Detoxification of olive mill wastewater using superabsorbent polymers. Environmental Technology, 25: 89-100.

El-Nakhlawy, F.S. 2010. Experimental Design and Analysis in Scientific 
Research. Sci. Pub. Center, King Abdulaziz University, Jeddah, Saudi Arabia.

El-Nakhlawy, F.S. and M. Ghandorah, 2010. Cultural practices of field crops production. Sci. Pub. Center, King Abdulaziz University, Jeddah, Saudi Arabia.

Garofalo, P. and M. Rinaldi, 2013. Water-use efficiency of irrigated biomass sorghum in a Mediterranean environment. Spanish Journal of Agricultural Research 11: 11531169.

Ghaafar, C., C.G. Abdel, I. Murad and T. Al-Rawi, 2014. Response of mungbean (Vigna radiata L., Wilczek) to gibberellic acid (GA3) rates and varying irrigation frequencies. International Journal of Biosciences (IJB), 1: 85-92.

Hamza, N.B., A.E. Idris, I.I. Elmunsor. A.I. Ibrahim and A.I. Abuali, 2016. Drought Tolerance Assessment in Grain Sorghum (Sorghum bicolor [L.] Moench) Genotypes Using Agro-morphological Traits and DNA Markers. International of Plant Breeding and Genetics, 10 : $125-135$.

Ihsan, M.Z., F.S. El-Nakhlawy and S M Ismail 2016. Wheat Phenological Development and Growth Studies As Affected by Drought and Late Season High Temperature Stress under Arid Environment. Front. Plant Sci., Vol 7: http://dx.doi.org/10.3389/fpls.2016 .00795 .

Ismail, S.M. 2012. Water use efficiency and bird pepper production as affected by deficit irrigation practice. International journal of Agriculture and forestry, 2, (5): 262-267.

Ismail, S.M. 2016. Maximizing production and irrigation water productivity of canola crop (Brassica napus L) under arid land conditions. Irrigation and Drainage: 65: 254-263.
Ismail, S.M. and M.H. Almarshadi, 2013. Effect of water distribution patterns on productivity, fruit quality and water use efficiency of Ziziphus jujube in arid regions under drip irrigation system. Journal of Food, Agriculture \& Environment 11: 373-378.

Khattak, R.A. and D. Muhammad, 2006. Effect of Pre-sowing seed treatments with humic acid on seedling growth and nutrient uptake. Internship Report, Department of Soil and Environmental Science, NWFP Agriculture.

Lindenmayer, B., N. Hansen, M. Crookston, J. Brummer and A. Jha, 2008. Strategies for reducing alfalfa consumptive water use. Hydrology Days, pp: 52-61.

Madani, A., A.H. Makarem, F. Vazin and M. Joudi, 2012. The impact of post-anthesis nitrogen and water availability on yield formation of winter wheat. Plant Soil and Environment 58: 9-14.

Mahajan, S. and N. Tuteja, 2005. Cold, salinity and drought stresses: An overview. Archives of Biochemistry and Biophysics 444: 139-158.

Mauromicale, G., M.G.L. Angela and A.L. Monaco, 2011. The effect of organic supplementation of solarized soil on the quality of tomato. Scientia Hort 129: 189-196.

Menezes, C..B., D.C. Saldanha, C.V. Santos, L.C. Andrade, M.P. Mingote Júlio, A. F. Portugal and F. D. Tardin, 2015. Evaluation of grain yield in sorghum hybrids under water stress. Genetics and Molecular Research 14: 12675-12683.

Mikkelsen, R. L. 2005. Humic materials for agriculture. Better Crops with Plant Food, 89: 6-7.

Miller, F.R. and J.A. Stroup, 2004. Growth and management of sorghum for forage production. 
http://alfalfa.ucdavis.edu/+symposi um/proceedings/2004/04-149.pdf

Mohamed, A., A. Bakry, Y.R.A. Soliman and S.A.M. Moussa, 2009. Importance of micronutrients, organic manure and bio-fertilizer for improving maize yield and its components grown in desert sandy soil. Res J Agric \& Bio Sci 5: 1623.

Sarir, M. S., M. Sharif, Z. Ahmed and M. Akhlaq, 2005. Influence of different levels of humic acid application by various methods on the yield and yield components of maize. Sarhad J Agric 21: 75-81.
Sarwar, M., S.I. Hyder, M. Akhtar, T. Tabassam and S. R. Malik, 2014. Integrated effects of humic acid and bio fertilizer on yield and phosphorus use efficiency in mungbean under rainfed condition. World Journal of Agricultural Sciences, 2 (3): 040-046.

SAS, 2006. SAS Institute Inc., Cary Nc., USA (Soft Ware Statistical Program).

Tejada, M. and J. L. Gonzalez, 2003. Effects of the application of a compost originating from crushed cotton gin residues on wheat yield under dryland conditions. Eur. J. Agron. 19: 357-368. 


\section{تعيم انتاجية محصول الذرة الرفيعة (Sorghum bicolor L.) تحت الري الكامل والاجهاد} المائي باستخدام حامض الهيونة الهيوميك في المناطق القاحلة

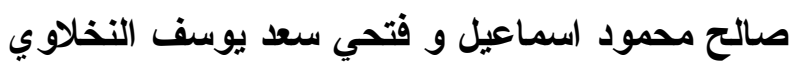

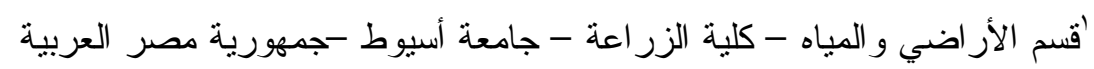

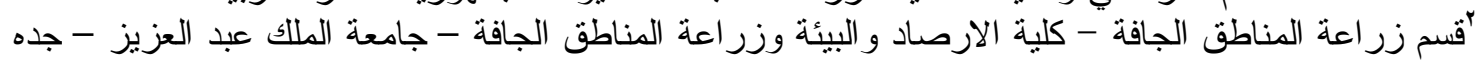

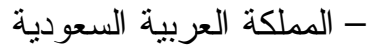

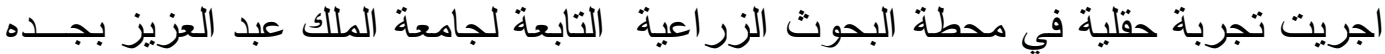

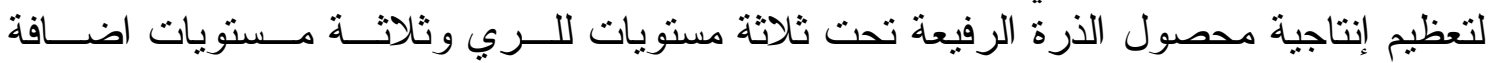

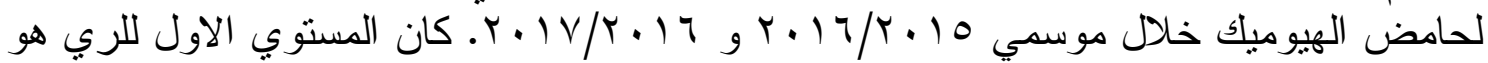

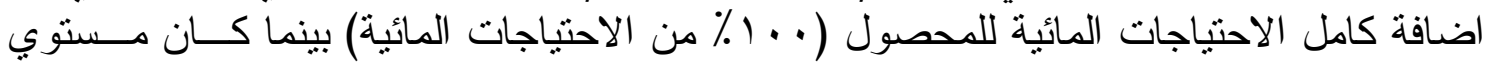

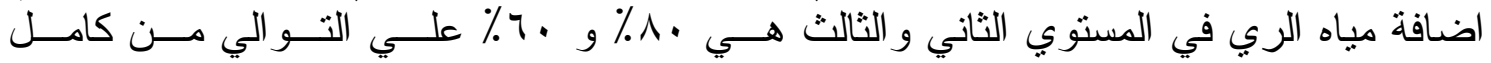

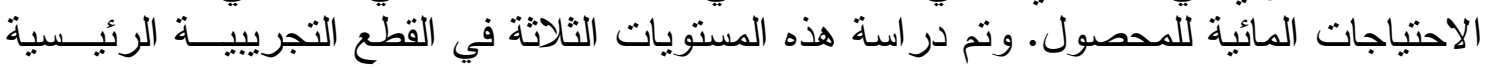

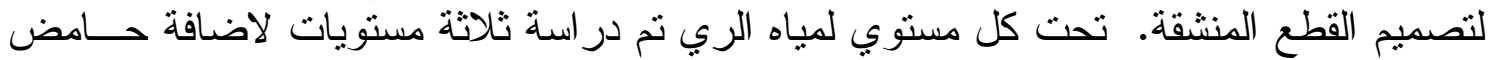

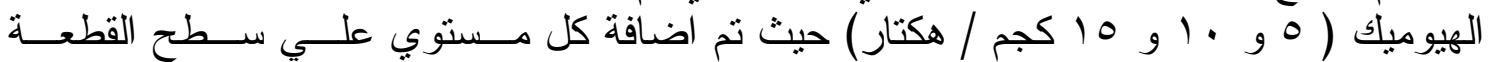

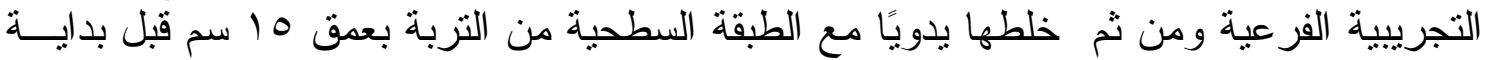

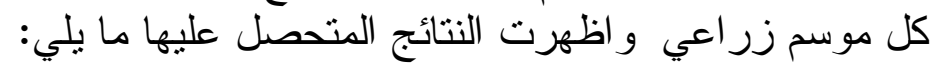

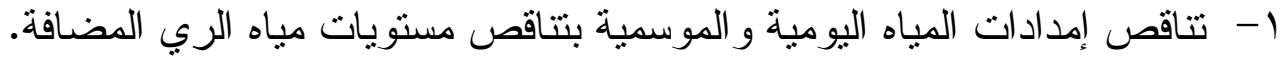

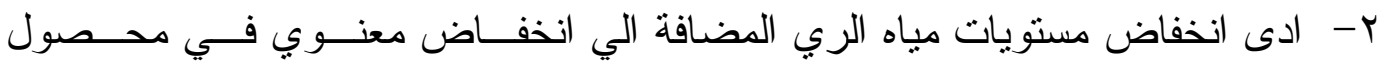

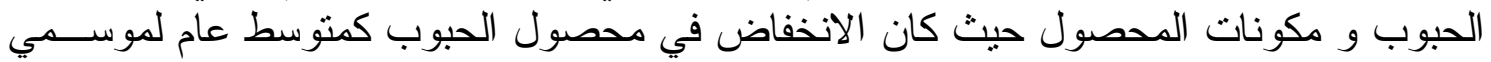

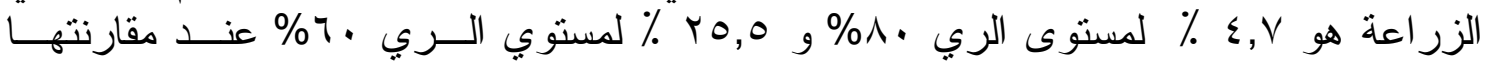
بمحصول الحبوب لمعاملة الري بكامل الاحتياجات المائية .

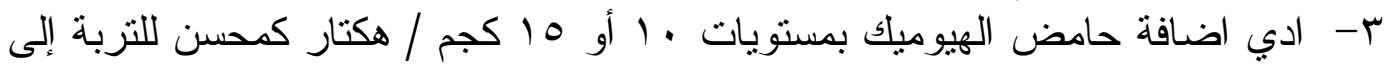

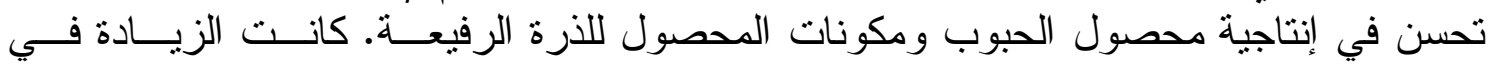

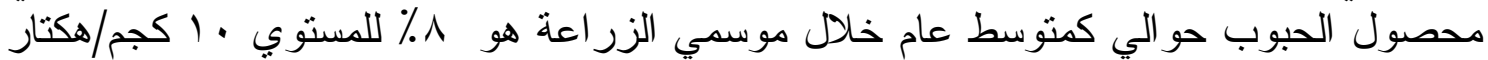

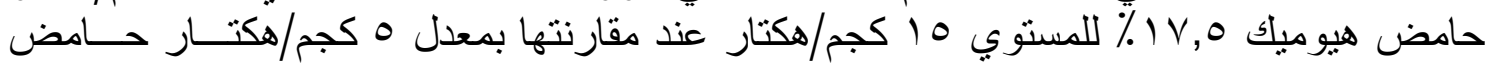
هيو ميك.

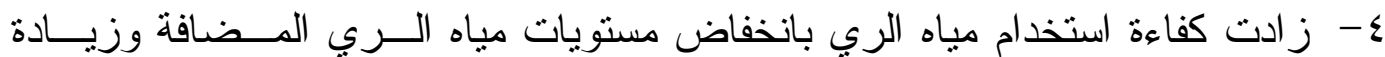

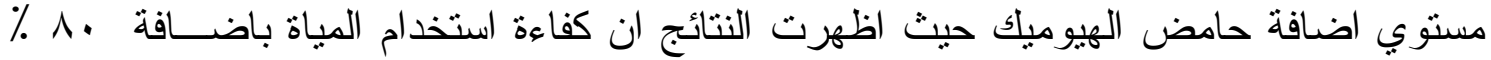

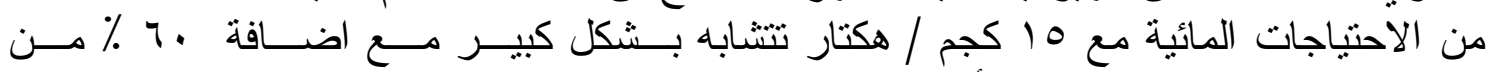

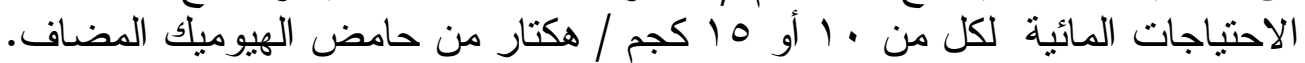

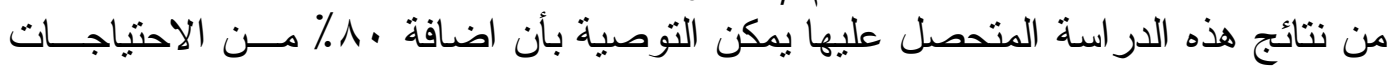

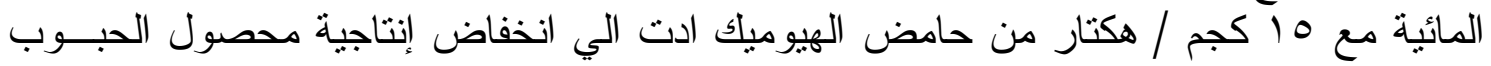

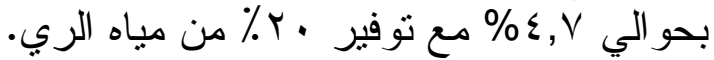
الكلمات الادالة: الاجهاد المائي - الري بالتنقيط - محسنات التربة - المناطق القاحلة 